Jovana M. Misaliović ${ }^{*}$

\title{
COLLECTIVE BARGAINING WITH SPECIAL REFERENCE TO THE LAW OF GERMANY AND REPUBLIC OF SERBIA
}

\begin{abstract}
Collective bargaining is type of dialogue between social partners (representative trade unions and representative employer organization) which lead to conclusion of collective agreement. For success of collective bargaining, it must necessarily be laid on a democratic basis and it must be in accordance with appropriate legal framework that enables the social partners to act autonomously and independently. This means that employees, on the one hand, and employers, on the other, have the right to freely choose to form their own organizations (trade unions and employers' organizations), and to join them under the conditions prescribed by their own statutes or rules.

The author considers right to collective bargaining as one of the cornerstone rights adopted by International Labour Organisation and give a special attention to legal framework and situation regarding collective bargaining in Germany and Republic of Serbia. labour law.

Keywords: collective bargaining, collective agreement, social dialogue, collective

\section{Collective bargaining: significance and importance}

The right to bargain collectively and conclude collective agreements is a collective right exercised in the function of protecting the collective interests of employees and employers. The subjects of the collective right to collective bargaining are the representative representatives of employees (trade unions) and the representative representatives of employers (employers' associations).

Collective bargaining is the process of negotiating which includes all kinds of bilateral and tripartite discussions of problems work-related issues that directly or indirectly affect workers (Bodiroga-Vukobrat \& Laleta, 2007, p. 6). In the narrow sense, collective bargaining involves the negotiation process between employers and employee representatives, as well as the agreement which contains binding rules (Blanpain, 1997, p. 570). In terms of collective law, collective bargaining is the process in which a representative trade union and a representative association of employers, while representing the interests
\end{abstract}

\footnotetext{
${ }^{\star}$ MA, Research Assistant, Institute of Comparative Law, Belgrade, Serbia, e-mail: j.misailovic@iup.rs.
} 
of their membership, with appropriate argumentation but also tolerance and willingness to yield and settle, try in good faith (bona fides) to determine the content, reach agreement and sign a collective agreement.

When it comes to the importance of collective bargaining, it should be highlighted that collective bargaining requires communication skills because, negotiation is a process of communication. Only if the parties communicate with each other negotiation is possible. If each party "relents" to its initial requirements, then a contract is concluded as a result of a compromise (Učur, 2006. p. 549).

In addition to the freedom of association, the effective recognition of the right to collective bargaining is fundamental principle of the highest importance. In regards to the promoting interest of workers and human dignity at work, social dialogue has an important role as a very valuable mean in order to extend democracy and workers' rights. Some of the very crucial questions for workers such as safety and health at the workplace, working conditions and wages have successfully been improved through collective bargaining, expending in this way scope of collective bargaining (The right to bargain collectively).

\section{Normative framework of collective bargaining: International Labour Organisation conventions}

Collective bargaining is fundamental to the International Labour Organization (in further text: ILO). Since the very founding of the ILO in 1919, collective bargaining has been acknowledged as an instrument of social justice (Convention No 154, Promoting collective bargainig, 2005, p. 5). Therefore, it is not surprising that, two Conventions that protect the collective bargaining rights of all workers including public sector employees, are included under the scope of those Conventions described as the "cornerstone documents" adopted by ILO, establishing in that way the base for this right (Carabetta, 2014, p. 278). These two Conventions are the Right to Organise and Collective Bargaining Convention No 98 (Right to Organise and Collective Bargaining Convention) and the Freedom of Association and Protection of the Right to Organise Convention No 87 (Freedom of Association and Protection of the Right to Organise Convention, No. 87).

Even though these Conventions are part of Core Labour Conventions, the ILO supervisory bodies have considered that these Conventions itself are not enough to provide wholly enforcement of the right to collective bargaining. According to recommendations some issues should have been included on the collective bargaining agenda as covering "the type of agreement to be offered to employees or the type of industrial instrument to be negotiated in the future, as well as wages, benefits and allowances, working time, annual leave, selection criteria in case of redundancy, the coverage of the collective agreement, the granting of trade union facilities, including access to the workplace beyond what is provided for in legislation etc." (See Digest of the Decisions of the Committee of Freedom of Association, 2006, p. 913). 
Fortunately, Conventions No 98 and No 87 have been acompanied by Collective Bargainig Convention No 154 adopted in 1981 which promotes freely and voluntarely collective bargainig (Collective Bargaining Convention, No. 154). The Collective Bargaining Convention No. 154 and its accompanying Recommendation No. 163 are key to furthering the promotion and implementation of the basic principles of Convention No. 98 in which, it is not specified how this is to be done. Contrary to Convention No 98, Convention No. 154 and Recommendation No. 163 show how it can be done in a practical way. Beacuse of its promotional character, Convention No. 154 is extremely accommodating and flexible, and acompanied by Recommendation No 163 contributes to the effective exercise of the right to collective bargaining. Due to its flexibility, Convention No. 154 can be easily implemented in countries with different economic and social situations, legislative frameworks and industrial relations systems. (Convention No 154, Promoting collective bargainig, 2005. pp. 4-5). It might be meaningful to mention that Convention No 154 sets out the goals which measures taken to promote collective bargaining should strive for, so as not to restrict the freedom of collective bargaining. Specifically, these goals relate to universality, progressive expansion, procedural rules and dispute resolution. (Convention No 154, Promoting collective bargainig, 2005, p. 7).

\section{Content of collective bargaining}

The subject of a collective agreement, considered as a consequence of successfully ended collective bargaining, is determined, in principle, by the relationship between the forces of workers and employers organizations. The strength and organization of both depends on which issues will be included in the negotiating agenda and on the content of the collective agreement.

According to International Labour Organisation reports from a few decades ago, the main issues that, now traditionally, override the interests of employees and employers in Europe are: "economic development and unemployment, wages, schedule, use of working hours and vacations, occupational safety, use capacity and redundancies etc. In essence, collective bargaining participants are free to determine the subject matter and content of the collective bargaining agreement" (Jovanović, 2009, p. 102). However, only what is in accordance with the law and good practices can be contracted.

The presumption of successful collective bargaining is the high level of organization of the social partners involved in the process. The theory and practice of European countries agree that, the main actors in collective bargaining are employers and workers with the participation of a state, objectively emerges as a participant with two significant attributes: as a regulator of general social relations with the prerogatives of the authorities and simultaneously as an employer in certain significant areas of work. Considering that collective bargaining implies equality of participants, the attitude of the state towards other social partners in the collective bargaining process is a criterion and measure of democracy in a society (Lakićević, 2011, p. 33). 
Finally, the goal of collective bargaining is replacement unilateral decision-making by employers in determining working conditions in order to prevail the weaker position of workers. The purpose of collective bargaining was (and remained primary) ensuring a balance of interests in the work process as well as an instrument that makes the union more favorable negotiator than an individual who would have to negotiate directly with an employer. (Herman \& Ćupurdija, 2011, p. 40)

\section{Collective bargaining in Germany}

Germany is well to the fore in terms of collective bargaining decentralisation in Europe (See Keune, 2011, pp. 86-94). In the international literature it is often regarded "as a standard case of 'organised' or 'controlled decentralisation', within the framework of which the bargaining parties at sectoral level define the scope for derogations at company level via so-called 'opening clauses" (Schulten \& Bispinck, 2017, p. 3). Summirised, decentralisation of collective bargaining may be considered as a delegation of competencies for collective bargaining to union workplace representatives. The roots of decentralisation in collective bargaining can be found in the increasing growth in the number of atypical employees, higher rates of unemployment, the greatly diminished costs of entry into industries, the increase in the number of small enterprises and so on (Vettori, 2005, p. 196).

In many European countries, Germany experiences are considered as an important role model for reform of national collective bargaining systems. The international perception of the German variant of decentralisation, however, does not reaect German collective bargaining in its all diversity. Two fundamental problems reflect decentralisation in the field of collective bargaining in German. „First, its development is very much viewed through the lenses of major manufacturing industries, such as chemicals or metalworking, which industrial relations regimes very much from those in other sectors, such as private services Secondly, the concept of 'organised decentralisation' often takes too rosy a view and underestimates the level of conflict" (Dribbusch et al., 2017).

As German experiences show clearly, collective bargaining decentralisation is not about a more or less 'intelligent' mode of regulation, but about different interests and power relations. It deals with the fundamental conflict between setting up a level playing field for all companies and recognising the specific interests and circumstances of individual firms. (Dribbusch et al., 2017). In the past few years the new trend towards decentralisation changed a lot the German collective bargaining system in that matter that organised and non-organised forms of decentralisation exist side by side, together with an overall trend toward the erosion of collective bargaining in some parts of the economy (Schulten \& Bispinck, 2017, p. 3), while the industry-wide bargaining in Germany is maintaining to be the main manifestation of collective bargaining in the vast majority in Europe, with the exception of eastern Europe (Bispinck et al., 2010).

Legally-wise what made the collective bargaining possible in Germany is Collective Agreements Act of 1949 (ger. Tarifvertragsgesetz). The parts in such agreements may be employers' associations (or individual employers) and trade unions. On the other hand, 
works councils - which represent the employees on a company level, are able to conclude solely works agreements.

Works agreements in Germany, as stated by the Works Constitution Act (ger. Betriebsverfassungsgesetz), 'may not deal with remuneration and other conditions of employment that have been fixed, or are normally fixed, by collective agreement'. (Betriebsverfassungsgesetz, Article 77, para. 3). The system in which unions' have the ability to conclude collective agreements, while works councils, even though are not part of union bodies, can arrange and supervise their execution on a company level is called in Germany a dual system of interest representation. All parties involved in such agreements are immediately bound by them, more precisely: employees that are included in the signatory unions and all companies that are members of such unions, or alternatively a single company if the agreement in question is a company agreement. In real life situations, employers that took part in a collective agreement most likely will respect and apply all provisions stated in the agreement to all employees, with or without them being a member of a trade union (Schulten \& Bispinck, 2017, p. 7). Having in mind 'favourability principle' (ger. Günstigkeitsprinzip), any derogations from collectively-agreed provisions are possible when they are favouring employees. For example, a works agreement can provide better employment conditions than a collective agreement, but otherwise can not be possible. ${ }^{1}$

Despite the favourability principle, employees are not fully protected because, the bargaining parties may agree on so-called 'opening clauses' in collective agreements. These clauses may allow, a derogation from collectively agreed standards, even though these clauses change employment conditions for the worse (WSI, 2019).

Although many European countries have been faced with a trend towards decentralisation of collective bargaining since the 1990s, this development has usually not led to a decline in the bargaining coverage. ${ }^{2}$ For example, in the UK since the 1980 s the company has become the dominant bargaining level. In contrast to that, most central and eastern European countries have predominately company bargaining with the exception of Slovenia which has established a sector-level bargaining system (Kohl, 2009).

\section{Collective bargaining in the Republic of Serbia}

Labour legislation of the Republic of Serbia contains solutions regarding the system of collective bargaining which are in accordance with international labour law. Such solutions provide to employers and employees safety that their rights are going to be fullfiled.

Having in mind the solution contained in the Labour Act of Republic of Serbia, employer is obliged to bargain. However, there is not any provision that forces employer to conclude a collective agreement and give more rights to the workers than he wants or can

\footnotetext{
${ }^{1}$ The same principle is valid in the Labour Law of the Republic of Serbia.

${ }^{2}$ Collective bargaining, like all other socio-economic rights, was almost completely marginalized in the EU Countries before the 1990s, when suddenly, thanks primarily to the provisions of the Maastricht Treaty, it gained in significance. We see the reasons for this change in the status of the right to collective bargaining in EU law primarily for economic reasons. More about collective bargainig in the EU See: Božičić, 2017, pp. 173-190.
} 
bear. Furthermore, Labour Act provides that a trade union, or association of employers, which has been established as representative in accordance with Labour Act, has the right to collective bargaining and to conclude a collective bargaining agreement at the appropriate level (Labour Law Act, Art. 239). A collective agreement must not contain provisions which give less rights or set less favourable employment conditions than the rights and conditions determined by the law, while collective agreement can contain only conditions which are more favourable for employees (Kulić et al., 2018).

Nonetheless, Labour Law of Republic of Serbia does not accept international labour standards regarding collective bargaining completely. Hence, it does not have needed infulence on social partners to make them to approach to the collective bargaining and afterwards to conclude collective agreement. In order to solve this kind of "problem", it is necessary for Republic of Serbia to ratify Convention 154 on collective bargaining and Recommendation 163 on collective bargaining. By implementing these two Acts adopted by ILO, the public authorities in Republic of Serbia will send clear sign that they are ready to support further development of social dialogue and to promote thorough legal regulations regarding collective bargaining (Urdarević et al., 2019, p. 100).

One may argue that a consequence or perhaps a reason too, for above mentioned lack could be found in the fact that in the Labour Law of the Republic of Serbia, General Collective Labour Agreement does not exist which lead to the fact that right to collective bargaining, as one of the most important rights in the field of labour law yet, does not have the status which it deserves. The last General Collective Labour Agreement was concluded in the 2008, (General Collective Labour Agreement) and it expired in the 2011, because of the expiry of the period to which it is contracted.

One more reason, may be found in the number of the concluded contracts at the company level, which, despite the needs and expectations, does not grow. According to that, it is justified to ask, what is the main obstacle for conclusion of a collective agreement. The reason for the underdeveloped collective bargaining at the lowest level, that is, perhaps can be found in the generally difficult economic situation in the country, due to which many employers are not even able to meet the level of employees' rights guaranteed by law, and especially not to raise their quality through collective agreements on the higher level.

The effective law enforcement affirmatively affects the development of consciousness workers and employers regarding the importance, role and dimensions of collective bargaining as an effective way to deal with economic and social issues problems, prevention and resolution of conflicts between them. Behavior of the social partners will develop gradually, primarily through the successful peaceful settlement of collective labour disputes and the regulation of mutual relations through collective bargaining and the conclusion of collective agreements. Even though social partners know that social dialogue and collective barganing are more useful than i.e. strike and other form of industrial action which potentially lead to further conflict they do not show willingness to make a compromise when it comes to specific questions (Mirjanić, 2013, p. 23). 


\section{Concluding remarks}

An essential element of freedom of association is the right to collective bargaining. That is why it is extremely important that trade unions have the right, through collective bargaining or other legal means, to seek to improve the living and working conditions of those whom they represent.

In addition, collective bargaining is an important form of social dialogue. Institutions for social dialogue and collective bargaining help protect the fundamental rights of workers, help provide social protection and promote sound industrial relations (Promoting collective bargaining Convention No. 154, 2011. p. 5)

In order to allow the right to collective bargaining to be enjoyed without any infringement, public authorities should refrain from any interference that would restrict this right or impede the lawful exercise thereof. Any such interference would lead to the breach of the principle of enabling workers and employers' organisations to enjoy the right to organise their activities and to formulate their programs. Any such interference would result in an infringement of the principle that workers and employers organisations should have the right to organise their activities and to formulate their programmes.

\section{References}

Bispinck, R., Dribbusch H. \& Schulten T. 2010. German Collective Bargaining in a European Perspective Continuous Erosion or Re-Stabilisation of Multi- Employer Agreements? Düsseldorf: Hans Böckler Stiftung, pp. 1-31.

Blanpain, R. 1997. Comparative Labour Law and Industrial Relations in Industrialised Market Economies. 5th ed., Deventer: Kluwer.

Bodiroga-Vukobrat, N. \& Laleta, S. 2007. Posebnosti kolektivnog pregovaranja u europskome i hrvatskome pravu. Zbornik Pravnog fakulteta Sveučilišta u Rijeci, 28(1), pp. 317-362.

Božičić, D. 2017. Normativni okvir za kolektivno pregovaranje u pravu Evropske Unije. Radno i socijalno pravo, 21(2), pp. 173-191.

Convention No 154, Promoting collective bargaining, 2005. Geneva: Internationa Labour Office. Dribbusch H., Lehndorff S. \& Schulten T. 2017. Two worlds of unionism? German manufacturing and service unions since the Great Recession. In: Lehndorff S., Dribbusch H. \& Schulten T. (eds.), Rough waters. European trade unions in a time of crises. Brussels: ETUI, pp. 197-220.

Herman, V. \& Ćupurdija, M. 2011. Osnove radnog prava. Osijek: Pravni fakultet Osijek.

Jovanović, P., 2009. Radnopravni standardi u vezi kolektivnog pregovaranja. Zbornik radova Pravnog fakulteta u Novom Sadu, 2, pp. 101-119.

Keune, M. 2011. Decentralizing wage setting in times of crisis? The regulation and use of wagerelated derogation clauses in seven European countries. European Labour Law Journal, 2(1), pp. 86-94. 
Kohl, H. 2009. Freedom of Association, Employees' Rights and Social Dialogue in Central and Eastern Europe and the Western Balkans. Berlin: Friedrich-Ebert-Stiftung.

Kulić, Ž., Milošević, G. \& Baturan, L. 2018. Labour market and collective bargaining in the Republic of Serbia. Zbornik radova Pravnog fakulteta Univerziteta u Nišu. LVII (78), pp. 149-167.

Lakićević, S. 2011. Socijalni dijalog i kolektivno pregovaranje. Beograd: Pravni fakultet Univerzitet Union.

Mirjanić, Ž. 2013. Socijalni dijalog - Izazovi u toku krize. Radno i socijalno pravo, 2, pp. 21-38.

Promoting collective bargaining Convention No. 154. 2011. Geneva: International Labour Office.

Schulten, T. \& Bispinck, R. 2017. Varieties of decentralisation in German collective bargaining. In.. Leonardi S. \& Pedersini R (eds.), Multi-employer bargaining under pressure Decentralisation trends in five European countries. Paris: OECD Publishing, pp. 105-151.

Stewart, A. \& Riley, J. 2007. Working around work choices: collective bargaining and the common law. Melbourne University Law Review, 31. pp. 903-936.

Učur, M. 2006. Kolektivno pregovaranje i proširenje primjene kolektivnog ugovora (oktroiranje kolektivnog ugvora). Zbornik Pravnog fakulteta Sveučilišta u Rijeci, 27(1), pp. 543-573.

Urdarević B. et al. 2019. Analiza stanja ekonomskih i socijalnih prava u Republici Srbiji. Beograd: Centar za dostojanstven rad.

\section{Website references}

Digest of the Decisions of the Committee of Freedom of Association. 2006. Available at: www.ilo.org/ilolex/english/ digestq.htm (8.11.2019).

Vettori, M.S. 2005. Alternative means to regulate the employment relationship in the changing world of work. Doctoral dissertation. Pretoria: University of Pretoria. Available at: https://repository.up.ac.za/handle/2263/29308, (13.11.2019).

WSI. 2019. Tarifpolitik: Statistisches Taschenbuch, Dusseldorf: Hans-Bockler-Stiftung. Available at: https://www.boeckler.de/pdf/p_ta_tariftaschenbuch_2019.pdf, (10.11.2019).

The right to bargain collectively General principles. Available at: https://www.ilo.org/ dyn/normlex/en/f?p=NORMLEXPUB:70002:0::NO:70002:P70002_HIER_ ELEMENT_ID,P70002_HIER_LEVEL:3947747,1, (12.11.2019).

\section{Legal sources}

Collective Bargaining Convention, 1981 (No. 154). Available at: https://www.ilo.org/ dyn/normlex/en/f?p=NORMLEXPUB:12100:0::NO::P12100_ILO_COD:C154, (26.11.2019).

Right to Organise and Collective Bargaining Convention, 1949 (No. 98). Available at: https://www.ilo.org/dyn/normlex/en/f?p=NORMLEXPUB:12100:0::NO::P12100_ INSTRUMENT_ID:312243, (26.11.2019) 
Freedom of Association and Protection of the Right to Organise Convention, 1948 (No. 87). Available at: https://www.ilo.org/dyn/normlex/en/f?p=NORMLEXPUB:1210 0:0::NO::P12100_INSTRUMENT_ID:312232, (26.11.2019).

General Collective Labour Agreement, Sl. glasnik RS, br. 50/2008, 104/2008 - Aneks I and 8/2009 - Aneks II.

Labour Act of Republic of Serbia, Sl. glasnik RS, br. 24/2005, 61/2005, 54/2009, 32/2013, 75/2014, 13/2017, 113/2017, 95/2018.

Betriebsverfassungsgesetz, $\$ 77$ Durchführung gemeinsamer Beschlüsse, Betriebsvereinbarungen. Available at: https://www.gesetze-im-internet.de/betrvg/_77.html, (18.11.2019).

Tarifvertragsgesetz. Available at:https://www.gesetze-im-internet.de/tvg/BJNR700550949. html, (18.11.2019).

\title{
Jovana M. Misailović, master
}

Istraživač pripravnik, Institut za uporedno pravo, Beograd, Srbija

e-mail: j.misailovic@iup.rs

\section{KOLEKTIVNO PREGOVARANJE UZ POSEBAN OSVRT NA PRAVO NEMAČKE I REPUBLIKE SRBIJE}

\author{
Sažetak
}

Kolektivno pregovaranje važan je oblik socijalnog dijaloga između socijalnih partnera - reprezentativne organizacije zaposlenih i poslodavaca. Institucije za socijalni dijalog i kolektivno pregovaranje pomažu u zaštiti osnovnih prava radnika, u pružanju socijalne zaštite i promovišu zdrave industrijske odnose. Sa stanovišta Međunarodne organizacije rada, koja je razvoj kolektivnog pregovaranja postavila kao jedno od primarnih ciljeva još od svog nastanka 1919. godine, kolektivno pregovaranje je važan put za radnike, poslodavce i njihove organizacije da postignu dogovor o pitanjima koja utiču na svet rada i radne odnose. Iako se kolektivno pregovaranje često smatra sporednim procesom kada je reč o njegovoj važnosti za unapređenje odnosa radnika i poslodavaca, trebalo bi ga češće koristiti za izgradnju poverenja između socijalnih partnera koje se može ojačati i dijalogom nakon okončanja pregovora, jer rešenja koja su izgrađena na poverenju uživaju istinsku podršku obe pregovaračke strane.

Kada je reč o implementiranju odredaba konvencija Međunarodne organizacije rada kojima se reguliše kolektivno pregovaranje u nacionalna zakonodavstva, uspešnost često može zavisiti od modela kolektivnog pregovaranja koji je u određenoj zemlji dominantan. Tako, na primeru Republike Srbije i Nemačke, može se potencijalno uvideti sa kojim problemima se ove dve zemlje susreću kada je reč o kolektivnom pregovaranju. 
Važno je naglasiti da nezavisno od sistema kolektivnog pregovaranja u svakoj od zemalja potpisnica konvencija Međunarodne organizacije rada kojima se reguliše kolektivno pregovaranje, ono mora biti uređeno na način da se slobodno pregovaranje radnika i poslodavaca o uslovima rada odražava kao suštinski element slobode udruživanja, a sindikatima radnika omogućava da kolektivnim pregovaranjem i drugim zakonitim sredstvima, poboljšaju uslove života i rada onih koje predstavljaju. Dodatno, državne vlasti ne smeju na bilo koji način ograničiti ovo pravo ili ometati njegovo zakonito sprovođenje, u suprotnom, krši se pravo radnika i organizacija poslodavaca da formulišu svoje programe i u skladu sa njima organizuju svoje aktivnosti.

Ključne reči: kolektivno pregovaranje, kolektivni ugovor, socijalni dijalog, kolektivno radno pravo.

Article history:

Received: 26 November 2019

Accepted: 27 January 2020 